Мила Матић*

Универзитет у Новом Саду

Филозофски факултет

Одсек за славистику
373.5:655.3.066.13]:373.3:811.161.1'243

https://doi.org/10.18485/zivjez.2021.41.1.10

Прегледни рад

Примљен 04/07/2021

Прихваћен 20/11/2021

\title{
КОНЦЕПЦИЈА И ЗНАЧАЈ СРЕДЫОШКОЛСКИХ ЧАСОПИСА У НАСТАВИ РУСКОГ ЈЕЗИКА - ПРИМЕР ФИЛОЛОШКЕ ГИМНАЗИЈЕ
}

Предмет нашег истраживања представља часопис Луч објављиван током 1990-1998. године од стране ученика Филолошке гимназије и спонзора школе. Поменути часопис је био јединствени пример сачуваног школског листа који је излазио на руском језику. Историјат овог часописа и његовог следбеника - часописа Логос, технички изглед и њихов садржај излажемо са циљем да подстакнемо оснивање сличних часописа ради популаризације руског језика у настави. На основу анализе садржаја представљени су тематика и жанрови ауторских текстова. У оквиру рада на оваквим ваннаставним активностима подстичемо ученике да развијају истраживачке особине, чиме доприносимо ефикаснијем, креативнијем усвајању страног језика, развијамо мотивацију за учење руског језика и формирамо свестрану личност. Закључили смо да школска периодика отвара нове погледе не само на ученичка интересовања која су их оформила, него и на школски живот уопште. Помоћу часописа наставници могу да обликују нови круг младих интелектуалаца који постају најбоља промоција школе.

Кључне речи: часопис, Филолошка гимназија, руски језик, методика наставе руског језика, талентовани ученици.

\section{1. Увод}

На писање овог рада подстакле су нас чињенице да Филолошка гимназија у Београду (у даљем тексту ФГ) има посебан друштвени статус, знатан број изузетних ученика који су похађали руско одељење, преко стотине одличних ученика-русиста и да представља ризницу талентованих младих филолога Србије. ${ }^{1}$ Запазили смо да у домаћој литератури нисмо наилазили

\footnotetext{
* У Универзитет у Новом Саду, Филозофски факултет, Др Зорана Ђинђића 1, 21000 Нови Сад; mila.matic@ff.uns.ac.rs

1 Филолошка и Карловачка гимназија у Сремским Карловцима су једине образовне институције у Србији специјализоване за образовање кадра филолошке струке. Широм Србије постоје језички смерови и филолошка одељења, али једино поменуте гимназије представљају праве филолошке гимназије.
} 
на слично спомињање часописа у настави страних језика. О часописима у настави страних језика се говори успутно (као део осавремењивања наставе или мотивације за учење страног језика) или поводом јубилеја излажења, као што је случај са часописима у методици наставе српског језика и књижевности ${ }^{2}$. На примеру школских часописа ФГ анализом садржаја видећемо како су ученици усвајање страног (у нашем случају руског) језика, књижевности и културе преносили на креативни ниво, чиме им је школа била ,[...] образовно пространство, у значајној мери културног, забавног карактера које им пружа мотивацију, а у којем они духовно узрастају."з (Пасов 2015: 24-25).

На темељима Друге београдске гимназије одабране ,[...] пре свега због њеног актуелног језичког усмерења у реформисаном школству [...]” (Јелачић-Србуљ 2016: 242-243) 1988. године оснива се огледно одељење ради „свестранијег и интензивнијег филолошког образовања младих” (Филолошка гимназија 1988: 2-3). Две године касније уписано је прво одељење ученика у школу новог назива и привремене локације - Филолошку гимназију у Београду. Након деветнаест година постојања, заједно са Карловачком гимназијом, одлуком министра просвете, ФГ добија статус школе од националног интереса 2007. године, а 2015. награду „Златни беочуг” за трајни допринос култури. Пре тридесет година формирана су четири одељења која су бројала 86 ученика и два смера - живих (енглески, француски, немачки и руски) и класичних језика (грчки и латински). У минулим деценијама број живих језика достигао је девет. На првобитан списак понуђених језика додати су шпански, италијански, кинески, јапански и норвешки језик. Према наставном плану и програму филолошких гимназија, ученици савладавају језичке компетенције одрабраног језика пет пута недељно на часовима редовне наставе. ${ }^{4}$

За тридесет година постојања руског језика у ФГ ова гимназија је изнедрила преко 600 ученика, што представља убедљиво највећи број младих филолога-русиста на територији читаве Србије. ${ }^{5}$ Поред главног садр-

2 Овде најпре мислимо на неколико истраживачких радова који се баве Школским тистом, првим српским педагошким часописом.

3 Овде и свуда - превод наш.

4 Филолошка и Карловачка гимназија су једине образовне установе у средњошколском систему Србије у којима се руски може учити као први страни језик, тј. које су имале и имају тзв. руско филолошко одельене.

5 Прикљупајући податке из школских летописа дошли смо до тачног броја ученика који су завршили руско одељење - 660. Међутим, услед малог броја уписаних ученика у другој и трећој деценији, ученици руског језика су пет пута спајани у одељење са ученицима који уче други језик, а које за потребе овог рада нисмо засебно пребројавали. У првој деценији (1990-2000) руски је завршило 228 ученика, у другој (2000-2010) 234, а у трећој (2010-2020) 198 ученика. 
жаја ваннаставних активности на руском језику које је ФГ пружала ђацима (пројекта промоције руског језика међу младима у Србији, поетских вечери и сл.), у првим годинама постојања руског језика у ФГ појављује се часопис Луч - круна сарадње талентованих ђака и ментора. Историјат, композиција и значај првог (испоставиће се и последњег) часописа који је објављиван на руском језику у некој српској средњој школи, а чији бројеви су скоро потпуно сачувани, представљају централну тему нашег истраживања.

\section{2. Историјат и концепција часописа}

Издавање часописа у ФГ почиње од оснивања школе, а већ шк. 1992/93. било их је шест ${ }^{6}$, ,„...] готово сваки језик има свој часопис на чијим страницама ученици почињу да пишу своја оригинална дела, да преводе на стране језике и са страног језика на српски језик. [...]" (Филолошка гимназија 1996: 4-5). Овим се ФГ уписала у историју. Наиме, сличне гимназије (најпре мислимо на Карловачку) традиционално издају неколико часописа посвећеним српском језику и књижевности или свим страним језицима који се уче у школи. Часопис Луч (Слика 1) излазио је од 1990. до 1998. године, а замишљен је као:

[...] часопис одсека за руски језик са темама из области руске књижевности, историје, сликарства, музике и савременог живота Русије. У овом часопису ученици се баве и преводилаштвом са руског и на руски језик, али и сопственим стваралаштвом на руском језику, пишући своје песме и друге литерарне форме на овом језику. [...] (Филолошка гимназија 1991: 49-50).

Часопис је излазио једном или два пута годишње. ${ }^{7}$ Издавање часописа су помагали ученици ФГ и спонзори школе. У зависности од прилика, часопис је имао око двадесетак, тридесетак страница штампаних црно-бело на једноставном папиру. Илустрације су осликаване руком, на исти начин су писани краћи прилози, док су дужи куцани на писаћој машини. Ликовно осмишљавање и техничко уређивање водили су ученици под менторством уреднице Милице Добрић, тадашње проф. руског језика и књижевности.

6 Шк. 1997/98. године издато је чак девет часописа, чиме ФГ постаје јединствени случај у свету. Према: Филолошка гимназија 1998: 26-27.

7 До 1998. године објављено је дванаест бројева, али у школској архиви нисмо успели да пронађемо три броја (6, 9. и 10.). 


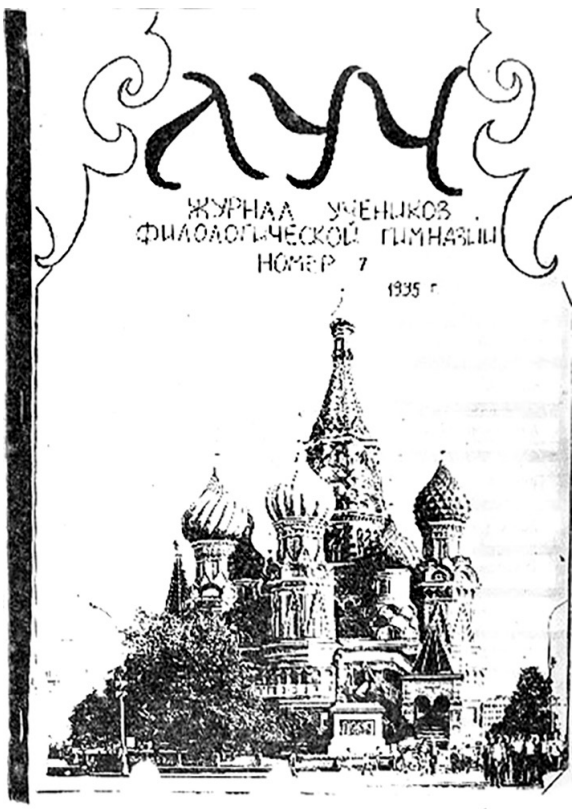

Слика 1. Насловна страна часописа Луч

За насловну страну свих бројева узет је један од најпознатијих симбола Русије - Храм Св. Василија Блаженог у Москви. Овим познатим избором чинило се као да редакција свима несвесно шаље позив за упознавање са руским светом. Техничка несавршеност часописа у супротности је са његовим садржајем. По примарном одређењу, Луч бисмо сврстали у књижевно-уметничко хумористички часопис. То одражава заинтересованост наших ученика за науку и шалу. Из ученичких пера настале су прве објављене ризнице критичких осврта на језик и уметност. Уређивачки састав следио је концепцију часописа у свим бројевима. Прве странице су биле посвећене актуелним догађајима у школи, руско-српском пријатељству, успесима на такмичењу и садржају текућег броја који су увек отварале књижевне теме. Текстови су били инспирисани годишњицама рођења-смрти (годишњица Јесењиновог рођења и смрти, педесетогодишњица од смрти Марине Цветаеве, а критички осврти писани на основу дела Достојевског (Унижен и оскорблён), Хармса (Феномен Даниила Хармса), Гогоља (В гостях у Пульхерии Ивановны и Афанасия Ивановича), Чехова (Дядя Ваня) или Мајаковс- 
ког («Облако в штанах» Маяковского). Упоредо са њима, посебно место су заузимали ауторски прилози надахнути прочитаним или светом око себе, као што су, на пример: Знакомство с Иваном Петровичем Петуховым; Всё хорошо, прекрасная маркиза; Кто существует? Была ли это шутка?; Это чудесное создание; Мой край; Дом Муму...). Пишући их на књижевном руском језику, наши млади писци су се придружили плејади познатих критичара, од којих је већина започела свој пут током школовања.

Следеће странице су посвећене музици и сликарству. Ове теме су заступљене у прилозима о Кандинском (Говорящие краски Кандинского), изложбама (Высставка русского искусства рубежа веков), Моцарту (Вольфганг Амадей), Шаљапину (Сын Шаляпина) и Висоцком. Прилози о обичајима, моди, религији и кухињи су били саставни део свих бројева, те тако у разним годинама срећемо текстове под називом: Осенняя и весенняя мода; Христианские праздники; Вера, Надежда, Любовь; Московский Свято-Данилов монастырь; Олег ПоПов - клоун на все времена; Русско-сербские связи; Каким должен быть мужчина?; «Святые птички»; Любите ли вы суп?; Салат - еда для всех; Родословная обеденной ложки; Русская кухня - типичный русский обед (рецепты)... Припремајући овакве текстове, ученици не само да усавршавају језичке компетенције, већ стичу и практична знања која ће им користити у будућности. Иако су технички услови деведесетих били скромнији у односу на данашње, краћи текстови праћени цртежима или елементима из текста, показују колико су чланови редакције били посвећени сваком детаљу ради задовољних читалаца. Након овог дела уследили су прилози из руске историје. Изгледа да је наше ђаке највише интересовала фигура Петра Првог, пошто су њему посветили два рада (један истоименог назива и други под називом Пётр Первый - наружсность, привычки, образ жизни и мыслей, характер). У овој целини, поред ауторских, поменућемо и значајне припремљене прилоге о Бородинској бици, царском поседу Коломенско и последњим данима царске породице. Сви прилози писани или припремани на страном језику сведоче да су се ученици ФГ свега након неколико година учења руског језика оспособили за креативно изражавање. ${ }^{8}$

Наставак композиције часописа чини интересантно поглавље - Переводческая мастерская (срп. Преводилачка радионииа). Можда управо тада српска култура добија прве нове комадиће мозаика преводне књижевности. У бројевима срећемо превод Распућиновог текста Рудольфио, затим Учебник глупостей Д. Андрића, Чеховљеве приче Уила, Солоухиновог одломка

8 Аутори чланака су углавном ученици другог, трећег и четвртог разреда. 
из текста Созериание чуда, Буњиновог текста Заря всю ночь и љубавних текстова, поезије Сељвинског, Вознесенског, Рождественског. Посматрајући превод очима Валтера Бенјамина, значај ове радионице огледа се у праћењу сазревања језика са којег се преводи и домишљатости младог преводиоца у решавању језичких недоумица. ${ }^{9}$ Објављени текстови то потврђују.

Завршне рубрике су се смењивале у зависности од броја: делу уголок юмора и Гороскоп додати су: кроссворд, психотест, викторина о России, анекдоты, анкета, этикет и комикс. У целини посматрано, одступања од композиције није било, али четврти број доноси две интересантне новине - рубрику Страниць филологии са текстовима о неким предлозима, фразеологизмима, типичним грешкама које правимо говорећи руски, паронимима итд. Вероватно најважнији део овог броја представља интервју са проф. Андрејем Тарасјевом, потомком „белих” Руса, који је био лектор у ФГ. Претпостављамо да је ово једини школски часопис за који је проф. Тарасјев говорио, чиме, опет, ФГ исписује нову страницу своје историје. ${ }^{10}$ Последњи број часописа Луч обележава највише ауторских прилога о себи, омиљеном другу, животу на пустом острву, томе какав (не) треба да буде наставник, почетку распуста. Иако мотиви, дужине прилога и језичке компетенције показују да су ђаци били дорасли оваквом задатку, испоставиће се да је осмогодишњица постојања часописа Луч био једини период када су гимназијалци стварали посебан уметнички свет на руском.

Како се уместо часописа Луч појављује Логос (Слика 2)? Услед недостатка материјалних средстава, ратних околности и опште оскудице који су завладали крајем деведесетих година прошлог века, природно је било очекивати да ће се часопис угасити. Није нам познато зашто је тек 2008. године решено да се покрене Логос, часопис за стране језике ученика ФГ. Претпостављамо да су разлози изнова били материјалне природе. ${ }^{11}$ Сада бројнија редакција овако представља нови часопис:

[...] Част нам је што смо у прилици да вам представимо први број часописа за стране језике ЛОГОС који обједињује креативно стваралаштво и истраживачки рад ученика Филолошке гимназије из области страних језика, култура и цивилизација. [...] Захваљујући великом таленту и свесрдном залагању ученика и одличној сарадњи представника актива за стране језике успели смо да осмислимо ча-

9 Мислимо на: Од свих литерарних форми превод је тај који надгледа сазреване језика изворника и порођајне болове сопственог језика.

10 Идеју интервјуисања руских лектора сматрамо изузетно корисном. Први сусрет ученика са доајенима славистике може умногоме одредити њихов даљи пут.

11 Из разговора са појединим члановима редакције споменут је и недостатак мотивације. 
сопис који, надамо се, неће бити занимљив само ученицима и професорима Филолошке гимназије већ и свима онима који буду желели да сазнају нешто више о различитим земљама и њиховим културама, историји, обичајима, књижевности итд. [...] (Филолошка гимназија 2008: 45-46).

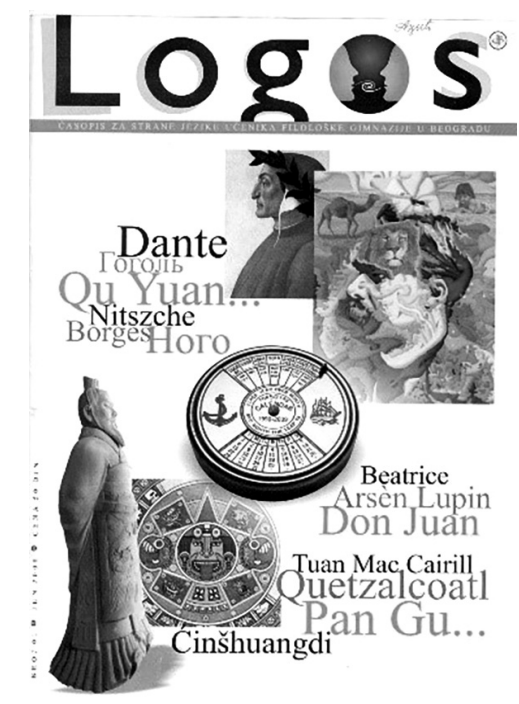

Слика 2. Насловна страна часописа Логос

У 2008. години руски језик више не заузима посебно место у школском издаваштву, већ чини део језичке слагалице, чему је и прилагођена насловница - неколико појмова на сваком језику праћени сликама-асоцијацијама које упућују на садржај броја. Озбиљнијег и уређенијег дизајна, штампан у боји, Логос је био обогаћен следећим рубрикама: Савремена књижевност; Умеће превођења; Наме мисли, наше речи; Језичке занимљивости; Успеси; Пут око света; Митологија; Обичаји, веровања; Представљамо вам и Занимљивости. Ђаци су понудили следеће прилоге на руском језику: превод текста Завещุание Флоренског, текст Кулич, биографију Л. Е. Улищкой, лингвистичке и линговкултуролошке текстове: Идиомы, Несколько разговорных фраз, Рязанская область, Леший, Новый год, филмску критику Тариф новогодний. Нова концепција подразумевала је краће чланке, али се то није одразило на њихов квалитет. Изврсно замишљен и усмерен не само на ученике ФГ, већ и на све заинтересоване за стране језике и цивилизације ЛоГос је 
престао да излази већ након другог броја. ${ }^{12}$ Од почетних шест, односно девет часописа, ФГ улази у тринаесту годину у којој не постоји ниједан часопис живих страних језика. Разлоге за престанак излажења часописа Логос, али и садашњег стања најпре видимо у преношењу тежишта на издавање друге литературе (на пример, годишњих Летописа ФГ, Зборника са конферениија, разних монографских публикација професора гимназије итд.).

На примеру концепције часописа ФГ и, свакако, једног од најважнијих окриља образовног система у коме се негује писана реч на српском и страном језику, анализирајући школску периодику, посматрајући деценије и године настанка часописа, закључујемо да се редакција оба часописа свесрдно трудила да друштву понуди квалитетан уметнички производ. Прилози писани на страним језицима одражавају висок ниво познавања руског језика, а преводилачки радови добре стазе по којима су ходали наши ученици. Напослетку, из садашње перспективе, у пренесеном смислу, можемо рећи да је рад на поменутим часописима имао за циљ да удаљи ученике од тешке свакодневице допустивши им да буду зрак (рус. луч) мрачног периода, односно глас, реч (грч. логос) своје генерације.

\section{3. Закључак}

Као што периодика једног краја говори о културном и историјском значају, тако и школски часописи отварају нове погледе на ученичка интересовања која су их оформила и на школски живот уопште. У ужем смислу, на основу анализе ових извора ФГ дошли смо до закључка да је тежак временски период деведесетих изнедрио више бројева него данашње стабилније време. Група обједињена око часописа Луч у погледу садржаја, а часописа Логос у погледу техничке савршености оставила нам је модел за надоградњу „личне карте” ове и свих школа.

У ширем смислу, уређивачком политиком којом професори подстичу ђаке да прикупљају и објављују радове, поред активирања њиховог инстраживачког рада, развијања креативности, обогаћивања лексичког фонда и откривања књижевних потенцијала, истовремено јача својеврсна сарадња професора и ученика. Размишљањем о прилозима, преводима и ауторским текстовима, професори директно утичу на усавршавање језичких компетенција ученика и њихове опште културе, јер помоћу њих могу усвајати „културу посредством језика и језик посредством културе.” (Пасов 2015: 134-135). Тиме часописи

12 Интересантно је да први број излази у јуну 2008. године, а други тек 2012. као двоброј. 
постају предмет у функцији стваралачког учења језика. Озбиљним искуством у стварању часописа наставници формирају нови круг интелектуалаца, чији доприноси постају слика школе и њена најбоља промоција.

Најзад, у оквиру ових ваннаставних активности стимулишемо ученике да развију све своје таленте, а уједно обликујемо свестране личности: „[...] правилно организоване, идејно усмерене и педагошки осмишљене вођене ваннаставне активности имају незаменљиву улогу у формирању свестрано развијене личности [...]" (Тодосијевић, Инђић 1988: 10-11). Уједно, анализом школске периодике отварамо ново перспективно поглавље, које треба да упозна научну јавност са подобним изврсним плодовима наших гимназија, али и да освести проблем образовања у несавесном односу према њој. ${ }^{13}$

\section{ИЗВОРИ}

Филолошка гимназија (1991-1998): Часопис Луч, Београд: Филолошка гимназија.

Филолошка гимназија $(2008,2012)$ : Часопис Логос, Београд: Филолошка гимназија.

\section{ЛИТЕРАТУРА}

Вранеш 2010: А. Вранеш, Библиографија часописа “Школски час српског језика и књижевности". Школски час српског језика и књижевности: часопис за методику наставе српског језика и књижевности, 1, 107-117.

Јелачић-Србуљ 2016: В. Јелачић-Србуљ, Филолошка гимназија - запис Друге београдске у Филолошкој гимназији 1870-2015. Београд: Филолошка гимназија.

Николић 2013: Љ. Николић, Тридесет година “Школског часа”: реч уредника. Школски час српског језика и књижевности: часопис за методику наставе српског језика и књижевности, 1, 3-4.

Пасов 2015: Е. Пассов, Методика как наука будущего. Краткая версия новой концепции. Санкт-Петербург: Златоуст.

Селихар 2010: К. Селихар, Први српски педагошки часопис “Школски лист”. Pedagoška stvarnost: časopis za školska i kulturno-prosvetna pitanja, 7/8, 669-680.

Тодосијевић и Инђић 1988: Тодосијевић, М, Инђић Б. Остваривање

13 Овде најпре мислимо на проблем архивирања и рециклирања школске периодике. 
васпитне функције ваннаставних активности ученика. Настава $и$ васпитање, XXXVII, бр. 1-2, 99-110.

Филолошка гимназија 1988: Izveštaj o ostvarivanju programa ogleda Filološke gimnazije za šk. 1988/89. godinu. Beograd: Filološka gimnazija. Филолошка гимназија 1991: Летопис Филолошке гимназије за шк. 1990/91. годину. Београд: Филолошка гимназија.

Филолошка гимназија 1995: Летопис Филолошке гимназије за шк. 1995/96. годину. Београд: Филолошка гимназија.

Филолошка гимназија 1998: Летопис Филолошке гимназије за шк. 1997/98. годину. Београд: Филолошка гимназија. 


\title{
Mila Matić
}

\section{CONCEPT AND SIGNIFICANCE OF SECONDARY SCHOOL MAGAZINES IN RUSSIAN LANGUAGE TEACHING - AN EXAMPLE OF PHILOLOGICAL HIGH SCHOOL}

\begin{abstract}
Summary
The subject of our research is the magazine Luch, published during 19901998. years by students of the Philological Gymnasium. In 1992 school published six school magazines. The mentioned magazine was and remains the only example of a school newspaper in a Serbian high school that was published in Russian. Conceived as a literary-artistic-humorous magazine, it contained: current events from school, literary and authorial texts, linguocultural texts, a translation workshop and a humorous part. The fourth issue brings a significant interview with prof. Andrej Tarasjev, the only one who found himself in a school magazine. Due to the lack of material resources, unfavorable social circumstances and other factors, in 1998 the publication of this magazine was stopped. It was not until 2008 that the school administration launched Logos, a new magazine of a different conception. This journal combines the creative work and research work of students of the Philological Gymnasium in the field of foreign languages, cultures and civilizations. With a more serious and orderly design, the Logos was enriched with the following sections: Contemporary Literature; Translation skills; Our thoughts, our words; Linguistic curiosities; Successes; Mythology etc. The most probable reasons for the cessation of publishing Logos are the publication of other school literature. In conclusion, we have shown that the analysis of school magazines opens new views on the student interests that shaped them and school life in general. Magazines occupy an important place in foreign language teaching because we use them to form versatile personalities.
\end{abstract}

Keywords: journal, Philological High School, Russian, teaching methodology of foreign language, talented students. 


\section{Мила Матич}

\section{КОНЦЕПЦИЯ И ЗНАЧЕНИЕ ЖУРНАЛОВ В ПРЕПОДАВАНИИ РУССКОГО ЯЗЫКА В СТАРШИХ КЛАССАХ - ПРИМЕР ФИЛОЛОГИЧЕСКОЙ ГИМНАЗИИ}

\section{Резюме}

Предметом нашего исследования является журнал «Луч», издававшийся в 1990-1998 гг. учащимися филологической гимназии. В 1992 году в школе издавалось шесть школьных журналов. Указанный журнал был и остаётся единственным примером школьной газеты в сербском образовании, которая издавалась на русском языке. Задуманный как литературно-художественно-юмористический журнал, он содержал: актуальные школьные события, литературные и авторские тексты, лингвокультурологические тексты, переводческую мастерскую и юмористическую части. В четвёртом выпуске появляется содержательное интервью с проф. Андреем Тарасьевым, единственным его интервью для школьного журнала. Из-за нехватки материальных средств, неблагоприятных социальных обстоятельств и других факторов, в 1998 году издание журнала было прекращено. В 2008 году школьная администрация запустила новый журнал - «Логос», имеющий иную концепцию. Журнал объединяет творческую работу учащихся филологической гимназии в области иностранных языков, культур и цивилизаций. С первых страниц мы замечаем его серьёзный дизайн. «Логос» был дополнен следующими разделами: Современная литература; Навыки перевода; Наши мысли, наши слова; Лингвистические курьёзы; Успехи; Мифология и др. Наиболее вероятными причинами прекращения публикации журнала «Логос» являются публикации другой школьной литературы. В заключение мы показали, что анализ школьных журналов открывает новые взгляды на формирующие интересы учащихся и школьную жизнь в целом. Журналы занимают важное место в обучении иностранным языкам, потому что, работая над ними, формирируем разносторонние личности.

Ключевые слова: журнал, Филологическая гимназия, русский язык, методика преподавания иностранных языков, талантливые ученики. 